\title{
Effects of Replacing Fishmeal with Soybean Products in Fish and Crustaceans Performance
}

\author{
Watson Ray Gyan ${ }^{1,2}$, Stephen Ayiku ${ }^{1,2}$, Qihui Yang ${ }^{1,2 *}$ \\ ${ }^{1}$ Laboratory of Aquatic Animal Nutrition and Feed, Fisheries College, Guangdong Ocean University, Zhanjiang, Guangdong 524025, P.R. \\ China; ' Key Laboratory of Aquatic, Livestock and Poultry Feed Science and Technology in South China, Ministry of Agriculture, Zhanjiang, \\ Guangdong 524025, P.R. China
}

\begin{abstract}
Fish meal (FM) is a principal dietary protein source in aquafeed. The rapid development of aquaculture resulted in high demand and a shortage of (FM) supply. The reason mentioned above has led to a search for an alternative protein sources as (FM) replacement in aquafeeds. Amongst plant protein ingredients, soybean meal (SB) is suggested as the most nutritive plant protein source but some contains high concentration of anti-nutritional factors. Among most soybean products compared with FM, soybean protein concentrate (SPC) is most suitable to replace fishmeal in aquafeed because of its high protein content and better amino acid profile than other soybean products such as soybean meal (SBM). Moreover, more SPC can be used to fully or partially replace FM as compared to SBM without adverse effects on growth performance and health condition in fish and crustaceans. This review reveals that SPC has positive effect on fish and crustaceans performance, gene expression and pathways. This information will help reduce the use of fishmeal by replacing it with SPC in aquafeed and also help to improve growth and health of fish and crustaceans.
\end{abstract}

Keywords: Aquafeed; Fish meal; Gene expression; Growth; Soybean Meal (SBM); Soybean Protein Concentrate (SPC)

\section{INTRODUCTION}

Production of world aquaculture in 2016 was 110.2 million tonnes with estimated value at USD 243.5 billion FAO [1]. This implies that aquaculture is important and also plays a major role in the world economy and market. Aquatic animals such as fish and crustaceans provide high-quality animal protein, selenium, and other essential nutrients in human and animal diets for healthy living. Despite their vital contribution to the global human and animal nutrition, culturing aquatic animals faces many challenges and among them is the high cost of feed [2], and increasing disease outbreak during culturing [3]. The price of aquafeed is always determined by the sources of ingredients and levels of nutritional composition that the feed possesses. Understanding fish and crustaceans nutrition is essential to aquaculturists when making decisions because the cost of the diet represents a large portion of the commercial fish and shrimp production cost. Similar to other terrestrial animals, these aquatic organisms requires a certain level of quality protein in their feed for maximum growth and healthy living in their culturing environment. Fish meal (FM) is a major dietary source protein for farmed marine fish and shrimp due to its high digestibility and good amino acid profile Sookying et al. [2]. Most fishes used in FM production are pelagic fishes from marine waters. FAO [4] reported that most world fish stocks of pelagic marine fish are either entirely or over-exploited. FM production experiences shortages from its raw material resources, decreasing the total FM production capacity make it difficult sustain the aquaculture industry. Such shortages cause low supply, which increases FM cost in the formulation of the aquafeed. High FM in aquafeed increases growth of aquatic animal but doubles production cost. Whenever this cost reflects on the selling price of farmed fish or shrimp, consumers are not willing to buy fish or shrimp product leading to reduced profit margin and unsustainability or non-expansion of the industry Sookying et al. [2]. In addition to economic incentives from replacing FM, significant pressure to improve the environmental sustainability of aquaculture has affected feed formulation practices in recent

Correspondence to: Qihui Yang, Laboratory of Aquatic Animal Nutrition and Feed, Fisheries College, Guangdong Ocean University, Zhanjiang, Guangdong 524025, P.R. China, Tel: +863828268896; E-mail: qihuiyang03@163.com

Received: August 12, 2019, Accepted: August 24, 2019, Published: August 30, 2019

Citation: Gyan WR, Ayiku S, Yang Q (2019) Effects of Replacing Fishmeal with Soybean Products in Fish and Crustaceans Performance. J Aquac Res Development, 10:573; doi: 10.35248/2155-9546.19.10.573

Copyright: @ 2019 Gyan WR, et al. This is an open access article distributed under the term of the Creative Commons Attribution License, which permits unrestricted use, distribution, and reproduction in any medium, provided the original work is properly cited. 
years. The production of one $(1 \mathrm{~kg})$ of shrimp currently requires an average, 2-3 kg of low fish species (herring, anchovy, horse mackerel, menhaden, sardine, pilchard, etc.). Aquaculture is frequently described (attacked) as an industry that merely converts fishes to fish. This concern has generated considerable research in aquatic animal nutrition to determine the best plant protein (PP) or alternative proteins with the same or close nutritional value to wholly or partially replace FM in aquafeed. Nutritional research has revealed that after FM, many protein sources can be obtained from animal and plant origin. Such sources are always available at a reduced price and can replace FM in aquafeed. For instance, animal proteins such as poultry by-product, meat, and bone meal are identified as good replacement FM in aquafeed Dersjant-Li [5]. Animal products contain good protein sources with low price thus; such products can be partially used to replace FM. However, due to animal disease such as bovine spongiform encephalopathy (BSE), consumers question the feeding practices on the basis of using animal proteins as raw materials in animal feed. In certain countries, animal proteins are banned in animal feed [5]. Therefore, future development of animal feed focuses on the vegetable-based formulation. Plant proteins are suitable for replacing FM. Among them, soybean (SB) product is mostly used in the partial replacement of FM in the aquafeed because of its availability and low price, better amino acids (AA) profile [6]. SB production in 2014 extended to 190 million tons and accounted for $62.5 \%$ of oil meals FAO [7]. The leading producers were China (54 MT), the USA (37 MT), Argentina (29 MT), Brazil (27 MT), and the European Union-28 (10 MT). The leading exporters were Argentina and Brazil (Oil World, 2015). The European Union-28 was the utmost importer of SBM (22 MT), followed by Southeast Asian countries such as Indonesia, Malaysia, Thailand, and the Philippines (Oil World, 2015). SB product is highly palatable feedstuff; soybean product is characterized by high protein content (from $43 \%$ to $93 \%$ ) and low crude fiber content. SB product has good amino acid balance and contains high lysine, tryptophan, threonine, and isoleucine, which are often lacking in cereal grains. Furthermore, SB can resist oxidation and spoilage and is naturally clean from organisms such as, fungus, viruses, and bacteria that are unsafe to shrimp González-Félix et al. [8]. However, SB contains several anti-nutritional factors (ANFs) such as trypsin inhibitors and lectins which requires processing before they can be used in the feed Zhou et al. [9]. ANFs may limit the usage of $\mathrm{SB}$ products in aquafeed, especially young animals with the still undeveloped digestive tract. In order to inactivate ANFs in SB, some techniques of processing were developed to process SB into other products such as soybean meal (SBM) and soybean protein concentrate (SPC) $[10,11]$. Replacements of FM with SB products present health issues and intestinal changes in aquatic organisms which affects growth, disease resistance and immune system of the aquatic animal. Therefore this review aims to discuss the effect of replacing fishmeal with soybean products such as SBM, and SPC in fish and crustacean performance such as growth, innate immune system, and gene expression. This information will be useful for fish farmers, aquatic nutritionist and other stakeholders in the aquaculture industry to improve growth performance, profits and sustainability in the aquaculture industry.

\section{LITERATURE REVIEW}

\section{SBM and its nutritional value}

SBM is the product residual after extracting most oil from whole SB. Such oil may be removed by solvent extraction or by an expeller process in which the beans are heated and squeezed. The standard process for solvent-extracted SBM production involves a series of treatments which include cracking, dehulling, flaking, and extraction, followed by desolventizing and toasting. SBM contains secondary compounds known as heat liable factors such as tripsin inhibitors, and lectins [12,13] and heat stable compounds such as starch polysaccharides, saponins, phytate, phytoestrogens [14-16]. These secondary compounds mentioned above reduce the efficient utilization of nutrient in the SBM product leading to a reduction in growth and immune system function in aquatic animals [17]. Oligosaccharide is also a secondary compound found in SB which is indigestible to finfish [18]. Oligosaccharide content in SB is about $15 \%$ more than in SPC which is 3\% [19]. Appropriate heat treatment in combination with the correct moisture level destroy some secondary compounds such as the trypsin inhibitors and lectins [20]. Insufficient heating, or under-processing, of SBM, negatively affects amino acid digestibility because ANFs are not adequately destroyed. Moreover, excessive heating or over-processing negatively affects amino acid digestibility because a portion of the amino acids either destroyed or tied up as indigestible, bound compounds [21]. SBM is more in protein and energy and is one of the most commonly used protein supplements in aquatic animal diets. Generally, full-fat and defatted (extruded or solvent-extracted) SBM contain 350-400 and 450-500 $\mathrm{gkg}^{-1}$ crude protein, respectively. SBM has poor AA profile than SPC as compared to FM Gatlin et al. [22]. One best way of comparing the quality and nutritional composition of other soybean products is to compare their lysine content. The reason is that lysine is a first limiting amino acid in non-ruminant animals and its absence may affect the growth and immune function of the animal such as fish [23].

\section{Soybean protein concentrates (SPC) and its nutritional value}

SPC is a product obtained during the processing of mature SB. High-quality SB are selected and cleaned as the first step in soybean product processing. Clean soybeans dehulled, and then the oil is extracted. The residue, consisting of defatted white flakes, can then be ground to make soy flour, toasted and grounded to make SBM, or subjected to further processing to produce value-added soy fiber and protein concentrate [24]. SPC is a clean protein source, with up to $65 \%$ protein content and a reduced concentration of ANFs NRC [25]. SPC has good amino acid levels equal to or greater than FM but deficient in methionine and lysine Drew et al. [19]. This extraction process removes the soluble carbohydrate and significantly lowers the ANFs, secondary compounds levels such as of lectins, trypsin inhibitors, glycinin, $\beta$-conglycinin, saponins, and oligosaccharides that are considered ANFs in regular SBM Drew et al. [21]. Figure 1 below shows processing of soybean into SBM and SPC, (Tables 1, 2 and 3) below also shows the chemical composition, amino acids composition, and anti-nutritional factors of SBM and SPC respectively.

\section{Utilization of SB products in Fish and Crustaceans}

Regarding the use of SB in aquafeed, different results are obtained in different studies. Such results may be related to the following aspects. First is the quality of SB products. SB products nutritional values are closely related and sometimes vary due to the source of $\mathrm{SB}$ ingredient and processing procedures. In most studies, ANFs not analyzed, leading to a difficulty in evaluating the relationship 


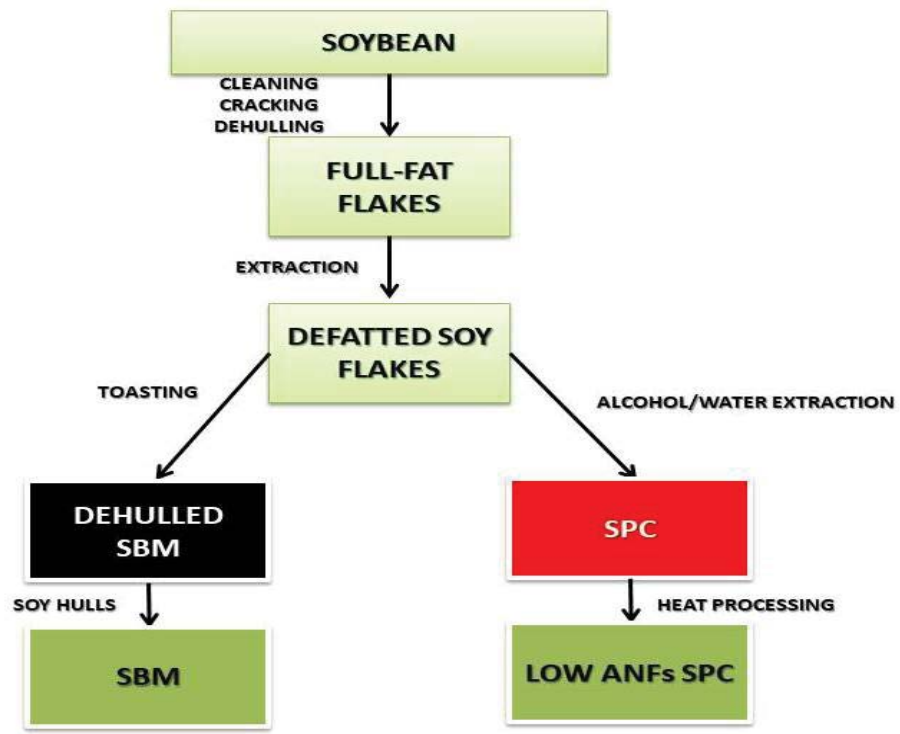

Figure 1: Flow chart showing the processes involved in producing SBM and SPC from soyabean.

\begin{tabular}{lccccc}
\hline $\begin{array}{l}\text { Alternative } \\
\text { SBM products } \\
\text { sources }\end{array}$ & $\begin{array}{c}\text { Dry } \\
\text { matter } \\
\mathbf{g} / \mathbf{k g}\end{array}$ & $\begin{array}{c}\text { Crude } \\
\text { protein } \\
\mathrm{g} / \mathbf{k g}\end{array}$ & $\begin{array}{c}\text { Crude fat } \\
\mathbf{g} / \mathbf{k g}\end{array}$ & $\begin{array}{c}\text { Crude } \\
\text { fiber g/kg }\end{array}$ & $\begin{array}{c}\text { Crude ash } \\
\mathbf{g} / \mathbf{k g}\end{array}$ \\
\hline $\begin{array}{l}\text { Soybean meal } \\
\text { (SBM) 44\% CP }\end{array}$ & 896 & 500 & 17 & 86 & 397 \\
\hline $\begin{array}{l}\text { Soybean meal } \\
\text { (SBM) 48\% CP }\end{array}$ & 909 & 518 & 47 & 69 & 365 \\
\hline $\begin{array}{l}\text { Soybean Protein } \\
\text { Concentrate }\end{array}$ & 920 & 636 & 5 & 45 & - \\
(SPC) & & & & & \\
\hline
\end{tabular}

Table 1: The chemical composition of test SBM and SPC (as-fed basis) [24].

\begin{tabular}{ccc}
\hline Amino acids & SBM & SPC \\
\hline Argenine & 6.7 & 6.4 \\
\hline Histidine & 2.4 & 2.5 \\
\hline Isoleucine & 4 & 4.1 \\
\hline Leucine & 6.7 & 6.6 \\
\hline Lysine & 5.1 & 5.5 \\
\hline Methionine & 1.1 & 1.2 \\
\hline Phenylananine & 4.6 & 4.5 \\
\hline Threonine & 3.7 & 3.5 \\
\hline Tryptophan & 1.5 & 1.3 \\
\hline Valine & 4.1 & 4.1
\end{tabular}

Table 2: Amino acids composition of SBM and SPC Sørensen et al. [26].

\begin{tabular}{lccc}
\hline $\begin{array}{l}\text { Antinutritional factors } \\
\text { (ANFs) }\end{array}$ & $\begin{array}{c}\text { Raw } \\
\text { SB }\end{array}$ & $\begin{array}{c}\text { Soybean meal } \\
\text { (SBM) }\end{array}$ & $\begin{array}{c}\text { Soybean protein } \\
\text { concentrate (SPC) }\end{array}$ \\
\hline Trypsin $(\mathrm{mg} / \mathrm{g})$ & 50 & 8 & 2 \\
\hline Lectins $(\%)$ & 3.5 & $<0.1$ & $<0.1$ \\
\hline Glycinin $(\mathrm{mg} / \mathrm{g})$ & 209 & 50 & $<0.1$ \\
\hline \multicolumn{1}{|c}{-conglycinin $(\mathrm{mg} / \mathrm{g})$} & 76 & 14 & $<0.1$ \\
\hline Stachyose $(\%)$ & - & 4.5 & 1.4 \\
\hline Raffinose $(\%)$ & - & 1.2 & 0.2 \\
\hline
\end{tabular}

Table 3: The anti-nutritional factors present in SBM and SPC [27].

between the quality of SB products and growth performance of animals. Second, is the nutritional balance in aquatic animal diets? Different studies have employed different diet formulations, thereby leading to a difference in amino acid (AA) profile and essential fatty acid composition. The reduced performance that are observed in individual studies may be related to nutrient imbalance of AA or presence of ANFs in SBM [26]. For example, at high $\mathrm{SB}$ product inclusion level, the methionine requirement should be considered and met by adding a methionine-rich ingredient or synthetic methionine Gatlin et al. [27]. Limiting of methionine may partly explain the reduced growth at high SB protein inclusion levels as observed in previous studies. When replacing FM with SB products, the nutritional balance in diets should be considered, including crude fat and minerals, FM and marine animal protein meals generally, contain more fat and minerals than SB protein. At high SB protein inclusion levels, mineral supplementation is also required. Phosphorous is the most severe mineral when formulating aquafeeds, which is contained a high level of SB protein (Akiyama, 1988b; Amaya, Davis, \& Rouse, 2007). Third, is the age of aquatic animal. Young animals are more vulnerable to dietary ANFs that can negatively influence digestion than old animals [28]. Therefore, only the best ingredients with little ANFs should be used in starter diets, to ensure a healthy and high growth rate. Table 4 show the effects of alternative SB products protein sources used in aquafeed.

\section{Effects of SBM on growth performance in Fish and Crustaceans performance}

Using complementary ingredients is a practice to obtain a balanced nutrient profile in feeds (that is essential amino acids, fatty acids, and minerals) and to increase nutrient utilization, and to facilitate feed processing [29]. In previous studies, FM (100 g/ kg diet) was removed entirely from diets for $L$. vannamei by combining plant and animal protein sources (SBM and poultry by-product meal) or all plant protein sources (SBM in combined with peanut meal, corn gluten and squid meals) Sookying et al. [2]. Such removals occur when diets are formulated to contain acceptable nutrient levels and properly balanced nutrients without any effect on survival, growth and feed palatability [30]. 45\% FM can replace SBM (reduction in FM from $40 \%$ to $22 \%$ ) without compromising growth performances, nutrient utilization and body composition of kuruma shrimp in the laboratory condition. This result can be a significant step forward to the development of cost-effective diets for kuruma shrimp [31]. Previous studies done by Abdel Rahman et al. [32] indicated that replacing FM with SBM up to $40 \%$ has no harmful effects on shrimp growth performance. Replacing FM with SBM in high levels may present palatability issue in fish. Therefore in their feed to increase feed intake in fish, attractant such as fish soluble must be included in the aquafeed Gatlin et al. [22].

\section{Effects of SBM on innate immune system and gene expression in Fish and Crustaceans}

According to De Jesús Becerra-Dorame et al. [33], hemolymph metabolite found in aquatic organisms such as shrimp signifies nutritional, morphological and immune stress indicators. Most aquatic organisms relies on the innate immune system to fight against pathogens because they has no adaptive immunity [34,35]. A study done by Hosseini, Khajepour and Biswas et al. [36,37] reported that hematological parameters and growth performance were reduced when SBM was used to replace fishmeal in beluga. These results may be linked to the present of ANFs in SBM which 
affected digestibility and bioavailability of nutrient in fish. Feed intake and apparent digestibility were not affected when SBM diet was used to feed fish. This is because low level SBM diet does not affect palatability but high SBM diet affected feed intake by the fish [38]. When SBM diet was used to feed fish, denteritis was observed in fish gut, also lysozyme and IgM was increased in the fish mid gut and intestinal mucosa as compared to SPC [39]. Even in low SBM diet, physiological changes in fish intestine will occur which might affect growth and immune system of the fish [40]. Huang [41], suggested that supplementation of mineral in SBM diet is vital to improve growth, metabolic activities in shrimp. Without the supplementation of minerals in SBM diet, growth performance, immune system, and mineral composition will be affected negatively because SBM lack some minerals such as calcium and selenium. Moreover, Baeverfjord \& Krogdahl [42], confirmed that high SBM inclusion in fish diet causes pathological changes in fish gut such as acute enteritis in the gut. This may affect fish growth and increase mortality in fish. The results above suggest that replacement of FM with high SBM diet may negatively affect growth performance, and immune system of the aquatic animal because of high content of ANFs in SBM $[15,43,44]$. Hepatic insulin-like growth factor-I (IGF-I) is a type of gene that contribute to muscle growth in fish [45]. There is a decrease in IGF-I axis genes when FM is replaced with SBM. SBM has positive correlation on IGF-I axis genes and this is because increasing inclusion of SBM in aquafeed reduces IGF-I axis genes thereby reducing growth performance in fish Kumar et al. [46]. Replacement of FM with SBM, leads to inflammation in fish gut $[47,48]$. Important immune factors that are linked to inflammation in fish gut include interleukins (ILs), and interferon regulatory factors (IRFs) [49]. Miao et al. [50], observed that replacement of FM with SBM up-regulated (IL-1 $\beta$, IL-10 and IL-17F) in fish. This suggests that replacement of FM with SBM can lead to inflammation in fish gut leading to high risk of diseases in fish.

\section{Effects of SPC on growth performance in Fish and Crustaceans}

It is crucial to further understand the potential for SPC in aquafeed, particularly regarding palatability and ANFs. SPC can be made to have less taste issues than SBM and may have greater flexibility in some species than SBM [51]. In replacing FM with SPC, amino acids and energy requirements need to be considered González-Félix et al. [8]. For example, methionine concentration in high SPC inclusion diet should be well balanced. In other to achieve a balanced nutritional composition in aquafeed, a diverse selection should be available when choosing feed ingredients. A mixture of feed ingredients can provide more balanced nutrients than only using limited feed ingredients to formulate aquafeed. Price of SPC is higher than FM depending on its supply, but given the instabilities and uncertainty in supply of FM, it is expected that SPC will be cost effective relative to the FM as aquaculture industry continues to advance. SPC feed formulations for pacilcwhite shrimp seem to work across many culture technologies (clear water research systems, outdoor tank systems, and research ponds) and a range of densities in outdoor ponds [52]. Given the range of culture systems and densities, an SPC feed formulation for aquatic animals are acceptable and appropriate for commercial production. In shrimp, the partial replacement of FM by SPC results in good growth performance, indicating an economic profit. Small shrimps are more sensitive to ANFs in SBM than large ones. Moreover, up to $120 \mathrm{~g} / \mathrm{kg}$ of SPC can be used in high SB diets under outdoor production conditions without affecting the production performance of shrimp [53]. Sá et al. [28], tested 31\% FM replacement for SPC including $20 \mathrm{~g}$ of fish oil per $\mathrm{kg}$ of feed. The results indicated that replacing $33 \%$ of the FM in the shrimp diet with SPC, including $25.1 \mathrm{~g}$ of marine lipids added per $\mathrm{kg}$ feed, does not harm shrimp performance. Therefore, for small shrimp, SPC can be a good substitute protein source for marine animal protein because of its high nutritional values of SPC as characterized by the high digestibility of amino acids and low ANFs. An experiment done by Bureau et al. [14] observed that salmon fed SPC obtained high weight gain in salmon fed SPC diet. This result suggests SPC improves growth as compared to SBM. As said by Yang [54], replacing $33 \%$ of FM with SPC on L. vannamei is possible by using a diet containing $40 \%$ of crude protein and 30\% FM. For large shrimp, combined SPC and SBM can be used to replace marine animal protein in diets. Also growth performance such as specific weight gain, and feed conversion ratio was improved when SPC was used to replace FM at 40\% [55]. A linear trend was found for final weight, weekly weight gain, total weight gain, and feed intake as replacement of FM by SPC increased. This implied that $75 \%$ FM replaced by SPC did not affect shrimp growth Soares et al. [56]. Biswas [57], reported that replacement of fishmeal with SPC at up to $70 \%$ without amino acid supplementation and attractant improves growth performance and digestibility in fish. Digestibility is an important criterion in evaluating the efficiency and utilization of replacing fishmeal with other plant proteins. Moreover low digestibility and ANFs are some of the factors influence the replacement of fishmeal with SPC Gatlin et al. [22]. Low ANFs and improved amino acids profile in SPC compared to SBM may be the reason for improved growth performance, digestibility, utilization, palatability in aquatic organisms Biswas et al. [58].

\section{Effects of SPC on innate immune function and gene expression in Fish and Crustaceans}

Nonspecific immunity exhibits a beneficial role in defense of the immune system in aquatic animals. Schleder et al. [59], reported that in a bacterial challenge test, shrimp fed 33\% and 66\% SPC showed low mortality rate linking it to the improved immune system of the shrimp as a result of SPC inclusion in aquafeed. Digestibility was improved, hematological parameters such as AST and ALT were not affected when FM was replaced by SPC at 70\% in fish Biswas et al. [57]. These results imply the health of the fish is improved so therefore farmer is assured of good harvest, and a high profit. Wang et al. [60], reported that SPC can totally replace FM in yellow croaker diet with without any adverse effect on growth and immune system. Hepatic insulin-like growth factor-I (IGF-I) is an important anabolic agent that can contribute to muscle growth in finfish [61]. There was no significant difference the expression of (IGF-I) when FM was replaced with SPC at 25\% but higher inclusion of SPC in fish diet reduced the, IGF-I expression. These suggest that replacement of FM with SPC can increase growth and disease resistance in fish. Target of rapamycin (TOR) is a vital nutrient sensitive pathway which is able regulates gene expression [62] and protein turn-over [63,64]. There was also a decrease in TOR expression in the liver of yellow croaker at higher inclusion of $\mathrm{SPC}$ in fish diet this implies the fish can tolerate culture condition Wang et al. (60). This implies that replacement of FM with SPC can 
affect the expression of genes in aquatic animals. To the best of our knowledge little study has been done about replacing fishmeal with plant protein especially SPC on gene expression is available. So therefore, this review suggests that more studies needs to be done on the replacement of FM with SB products on gene expression in aquatic animals.

\section{CONCLUSION AND RECOMMENDATIONS}

This review reveals that SPC is an excellent protein source for aquafeeds than other soybean product such as SBM with the reason being that SPC contains high crude protein content and better amino acid profile than SBM. Moreover, more SPC quantities can be used to substitute FM as compared to SBM without any adverse effects on growth performance and also it improves the immune structure and function in fish and crustaceans when added to their feed. Thus, this makes SPC a suitable alternative protein source in the aquaculture industry. Increasing collaboration among feed producers, ingredient suppliers, fish producers, and research organizations can also be instrumental in improving the quality and significance of aquatic nutrition research in recent years. Such an improved collaboration can also set the stage for the significant reduction of FM levels in commercial aquafeeds. Therefore, as the use of SPC becomes widespread in aquafeeds and as market prices become economical, aquafeed formulation can lessen its dependence on or become entirely independent of FM. This will increase profit, improve the aquaculture industry and also help curb overfishing in our oceans and seas.

\section{ACKNOWLEDGMENT}

The Special Fund for Agro-scientific Research financially assisted this work in the Public Interest of China (201003020), the Guangdong Natural Science Foundation of China (2015A030313621; 2016A030313749), the Industry Technology and Development Special Fund Project of Guangdong Province (2013B021100017). We are grateful to the Key Laboratory of Aquatic, Livestock and Poultry Feed Science and Technology in South China, Ministry of Agriculture, for providing technical assistance.

\section{REFERENCES}

1. FAO. The State of Fisheries and Aquaculture in the World 2018. FAO Org. 2018;17-23.

2. Sookying D, Davis DA, Silva SD. A review of the development and application of soybean-based diets for Pacific white shrimp Litopenaeus vannamei. Aquac Nutr. 2013;19:441-448.

3. Gyan WR, Ayiku S, Yang JA. Effects of yeast antimicrobial peptide in aquaculture. J Fish Aquac Dev. 2019;6.

4. FAO. Fisheries and aquaculture department. The state of world fisheries and aquaculture. SOFIA. FAO Fisheries and Aquaculture Department, 2014.

5. Dersjant-Li Y. The use of soy protein in aquafeeds. 2002;6:543.

6. Lemos D, Ezquerra JM, Garcia-Carreño FL. Protein digestion in penaeid shrimp: Digestive proteinases, proteinase inhibitors and feed digestibility. Aquaculture. 2000;186:89-105.

7. FAO. Faostat. Food Balance Sheets. Faostat: Food Balance Sheets. 2016. http://faostat.fao.org/beta/en/\#data/FBS. Accessed 21/11/2016.

8. González-Félix ML, Davis DA, Rossi W, Perez-Velazquez M, Kütter MT. The use of soy aquaculture. 2009; 12:541-558.
9. Zhou F, Song W, Shao Q, Peng X, Xiao J. Partial replacement of fish meal by fermented soybean meal in diets for Black Sea Bream, Acanthopagrus schlegelii, Juveniles. J World Aquac Soc. 2011;42:184197.

10. Kader MA, Bulbul M, Koshio S, Ishikawa M, Yokoyama S. Effect of complete replacement of fishmeal by dehulled soybean meal with crude attractants supplementation in diets for red sea bream, Pagrus major. Aquaculture. 2012.

11. Gamboa-Delgado J, Rojas-Casas MG, Nieto-López MG, Cruz-Suárez LE. Simultaneous estimation of the nutritional contribution of fish meal, soy protein isolate and corn gluten to the growth of Pacific white shrimp. Litopenaeus vannamei using dual stable isotope analysis. Aquaculture. 2013;383:33-40.

12. Francis G, Makkar HPS, Becker K. Anti-nutritional factors present in plant-derived alternate fish feed ingredients and their effects in fish. Aquaculture. 2001.

13. Refstie S, Storebakken T, Baeverfjord G, Roem AJ. Long-term protein and lipid growth of Atlantic salmon. Salmo salar fed diets with partial replacement of fish meal by soy protein products at medium or high lipid level. Aquaculture. 2001.

14. Bureau DP, Harris AM, Young Cho C. The effects of purified alcohol extracts from soy products on feed intake and growth of chinook salmon. Oncorhynchus tshawytscha and rainbow trout, Oncorhynchus mykiss. In: Aquaculture. 1998.

15. Hendriks HGCJM, Van den Ingh TSGAM, Krogdahl Å, Olli J, Koninkx JFJG. Binding of soybean agglutinin to small intestinal brush border membranes and brush border membrane enzyme activities in Atlantic salmon. Salmo salar). Aquaculture. 1990).

16. Rumsey GL, Hughes SG, Winfree RA. Chemical and nutritional evaluation of soya protein preparations as primary nitrogen sources for rainbow trout, Oncorhynchus mykiss. Anim Feed Sci Technol. 1993.

17. Refstie S, Førde-Skjærvik O, Rosenlund G, Rørvik KA. Feed intake, growth, and utilisation of macronutrients and amino acids by 1 - and 2-year old Atlantic cod, Gadus morhua fed standard or bioprocessed soybean meal. Aquaculture. 2006.

18. Refstie S, Storebakken T, Roem AJ. Feed consumption and conversion in Atlantic salmon, Salmo salar fed diets with fish meal, extracted soybean meal or soybean meal with reduced content of oligosaccharides, trypsin inhibitors, lectins and soya antigens. Aquaculture. 1998.

19. Drew MD, Borgeson TL, Thiessen DL. A review of processing of feed ingredients to enhance diet digestibility in finfish. Anim Feed Sci Technol. 2007;138:118-36.

20. Arndt RE, Hardy RW, Sugiura SH, Dong FM. Effects of heat treatment and substitution level on palatability and nutritional value of soy defatted flour in feeds for Coho Salmon, Oncorhynchus kisutch. Aquaculture. 1999.

21. Drew MD, Borgeson TL, Thiessen DL. A review of processing of feed ingredients to enhance diet digestibility in finfish. Animal Feed Science and Technology. 2007.

22. Gatlin DM, Barrows FT, Brown P, Dabrowski K, Gaylord TG. Expanding the utilization of sustainable plant products in aquafeeds: A review. Aquaculture Research. 2007.

23. Cromwell D. Soybean meal-An exceptional protein source. 2015-0129. $2008 ; 1-15$.

24. Bulletin T. Soy protein concentrate: How soy protein concentrate is manufactured types of soy protein concentrate specifications for aquaculture feeds. 2008.

25. National Research Council. Nutrient requirements of fish and shrimp. Aquaculture International. 2011;376. 
26. Sørensen M, Berge GM, Thomassen M, Ruyter B, Hatlen B. Today's and tomorrow's feed ingredients in Norwegian aquaculture. 2011;68.

27. Ton Nu MA, Laue A. Anti-nutritional factors in soy proteins - The view of the nutritionist. Int Pig Top. 2016;31:7-8.

28. Sá MVC, Sabry-Neto H, Cordeiro-Júnior E, Nunes AJP. Dietary concentration of marine oil affects replacement of fish meal by soy protein concentrate in practical diets for the white shrimp, Litopenaeus vannamei. Aquac Nutr. 2013;19:199-210.

29. Amaya EA, Davis DA, Rouse DB. Replacement of fish meal in practical diets for the Pacific white shrimp. Litopenaeus vannamei reared under pond conditions. Aquaculture. 2007;262:393-401.

30. Sookying D, Davis DA. Pond production of Pacific white shrimp. Litopenaeus vannamei fed high levels of soybean meal in various combinations. Aquaculture. 2011;319:141-149.

31. Bulbul M, Koshio S, Ishikawa M, Yokoyama S, Abdul Kader M. Growth performance of juvenile kuruma shrimp, Marsupenaeus japonicus. Bate fed diets replacing fishmeal with soybean meal. Aquac Res. 2015;46:572-580.

32. Abdel Rahman SH, Abdel Razek FA, Goda AMAS, Ghobashy AFA, Taha SM, Khafagy AR. Partial substitution of dietary fish meal with soybean meal for speckled shrimp, Metapenaeus monoceros. Fabricius, 1798; Decapoda: Penaeidae juvenile. Aquac Res. 2010;41.

33. De Jesús Becerra-Dorame M, Martinez-Cordova LR, Martínez-Porchas M, Hernández-López J, López-Elías JA. Effect of using autotrophic and heterotrophic microbial-based-systems for the pre-grown of Litopenaeus vannamei, on the production performance and selected haemolymph parameters. Aquac Res. 2014.

34. Duan Y, Liu P, Li J, Wang Y, Li J. Molecular responses of calreticulin gene to Vibrio anguillarum and WSSV challenge in the ridgetail white prawn Exopalaemon carinicauda. Fish Shellfish Immunol. 2014.

35. Zhang Q, Li F, Zhang X, Dong B, Zhang J. cDNA cloning, characterization and expression analysis of the antioxidant enzyme gene, catalase, of Chinese shrimp Fenneropenaeus chinensis. Fish Shellfish Immunol. 2008.

36. Hosseini SA, Khajepour F. Effect of partial replacement of dietary fish meal with soybean meal on some hematological and serum biochemical parameters of juvenile beluga, Huso huso. Iran J Fish Sci. 2013;348-356.

37. Biswas AK, Kaku H, Ji SC, Seoka M, Takii K. Use of soybean meal and phytase for partial replacement of fish meal in the diet of red sea bream, Pagrus major. Aquaculture. 2007.

38. Zhang YQ, Wu YB, Jiang DL, Qin JG, Wang Y. Gamma-irradiated soybean meal replaced more fish meal in the diets of Japanese seabass. Lateolabrax japonicus). Anim Feed Sci Technol. 2014.

39. Krogdahl Å, Bakke-Mckellep AM, Roed KH, Baeverfjord G. Feeding Atlantic salmon Salmo salar L. soybean products: Effects on disease resistance, furunculosis, and lysozyme and IgM levels in the intestinal mucosa. Aquac Nutr. 2000.

40. Sanden M, Berntssen MHG, Krogdahl Å, Hemre GI, Bakke-McKellep AM. An examination of the intestinal tract of Atlantic salmon, Salmo salar L., parr fed different varieties of soy and maize. J Fish Dis. 2005.

41. Huang F, Wang L, Xiao ZC, Song K. Replacement of fishmeal with soybelan meal and mineral supplements in diets of Litopenaeus vannamei reared in low-salinity water. Aquaculture. 2017;473:172-180.

42. Baeverfjord G, Krogdahl Å. Development and regression of soybean meal induced enteritis in Atlantic salmon, Salmo salar L., distal intestine: A comparison with the intestines of fasted fish. J Fish Dis. 1996.

43. Kikuchi K. Use of defatted soybean meal as a substitute for fish meal in diets of Japanese flounder. Paralichthys olivaceus). Aquaculture. 1999.
44. Wu GS, Chung YM, Lin WY, Chen SY, Huang CH. Effect of substituting de-hulled or fermented soybean meal for fish meal in diets on growth oh hybrid tilapia, Oreochromis niloticus $\times$ O. aureus. J Fish Soc Taiwan. 2003;30:291-7.

45. Ma J, Liu Y, Li Y, Zhang J, Zhao N. Effects of dietary fat and protein nutrition on fat metabolic enzymes and growth-associated gene expression of Atlantic salmon, Salmo salar in the recirculating aquaculture system. J Fish Sci China. 2017;24.

46. Kumar S, Sándor ZJ, Nagy Z, Fazekas G, Havasi M. Potential of processed animal protein versus soybean meal to replace fish meal in practical diets for European catfish. Silurus glanis: Growth response and liver gene expression. Aquac Nutr. 2017.

47. Bakke-McKellep AM, Penn MH, Salas PM, Refstie S, Sperstad S. Effects of dietary soyabean meal, inulin and oxytetracycline on intestinal microbiota and epithelial cell stress, apoptosis and proliferation in the teleost Atlantic salmon. Salmo salar L.). Br J Nutr. 2007.

48. Lilleeng E, Penn MH, Haugland $\varnothing$, Xu C, Bakke AM. Decreased expression of TGF-, GILT and T-cell markers in the early stages of soybean enteropathy in Atlantic salmon. Salmo salar L. Fish Shellfish Immunol. 2009.

49. Marjara IS, Chikwati EM, Valen EC, Krogdahl Å, Bakke AM. Transcriptional regulation of IL-17A and other inflammatory markers during the development of soybean meal-induced enteropathy in the distal intestine of Atlantic salmon. Salmo salar L.). Cytokine. 2012.

50. Miao S, Zhao C, Zhu J, Hu J, Dong X. Dietary soybean meal affects intestinal homoeostasis by altering the microbiota, morphology and inflammatory cytokine gene expression in northern snakehead. Sci Rep. 2018.

51. Forster IP, Dominy W, Tacon AGJ. The use of concentrates and other soy products in shrimp feeds. In: Avances en Nutrición Acuícola VI Memorias del VI Simposium Internacional de Nutrición Acuícola 3 al 6 de Septiembre del Cancún, Quintana Roo, México. 2002;527-540.

52. Sookying D, Silva FSD, Davis DA, Hanson TR. Effects of stocking density on the performance of Pacific white shrimp Litopenaeus vannamei cultured under pond and outdoor tank conditions using a high soybean meal diet. Aquaculture. 2011;319:232-239.

53. Sookying D, Davis DA. Use of soy protein concentrate in practical diets for Pacific white shrimp. Litopenaeus vannamei reared under field conditions. Aquac Int. 2012;20:357-371.

54. Yang Q, Tan B, Dong X, Chi S, Liu H. Effect of replacing fish meal with extruded soybean meal on growth, feed utilization and apparent nutrient digestibility of juvenile white shrimp, Litopenaeus vannamei. J Ocean Univ China. 2015;14:865-872.

55. Bauer W, Prentice-Hernandez C, Tesser MB, Wasielesky W, Poersch LHS. Substitution of fishmeal with microbial floc meal and soy protein concentrates in diets for the pacific white shrimp Litopenaeus vannamei. Aquaculture. 2012;343:112-116.

56. Soares M, Fracalossi DM, De Freitas LEL, Rodrigues MS, Redig JC. Replacement of fish meal by protein soybean concentrate in practical diets for Pacific white shrimp. Rev Bras Zootec. 2015;44:343-349.

57. Biswas A, Araki H, Sakata T, Nakamori T, Takii K. Optimum fish meal replacement by soy protein concentrate from soymilk and phytase supplementation in diet of red sea bream, Pagrus major. Aquaculture. 2019.

58. Biswas A, Araki H, Sakata T, Nakamori T, Kato K. Fish meal replacement by soy protein from soymilk in the diets of red sea bream, Pagrus major. Aquac Nutr. 2017.

59. Schleder DD, Jatobá A, da Silva BC, Ferro DPD, Seiffert WQ. Soybean protein concentrate in pacific white shrimp reared in bioflocs: Effect on health and vibrio challenge. Acta Sci Anim Sci. 2018;40. 
60. Wang P, Zhu J, Feng J, He J, Lou Y. Effects of dietary soy protein concentrate meal on growth, immunity, enzyme activity and protein metabolism in relation to gene expression in large yellow croaker Larimichthys crocea [Internet]. Vol. 477, Aquaculture. 2017;15-22.

61. Barton-Davis ER, Shoturma DI, Sweeney HL. Contribution of satellite cells to IGF-I induced hypertrophy of skeletal muscle. In: Acta Physiologica Scandinavica. 1999.

62. Rolland M, Dalsgaard J, Holm J, Gómez-Requeni P, Skov PV. Dietary methionine level affects growth performance and hepatic gene expression of GH-IGF system and protein turnover regulators in rainbow trout. Oncorhynchus mykiss fed plant protein-based diets. Comp Biochem Physiol Part - B Biochem Mol Biol. 2015.

63. Bower NI, Johnston IA. Transcriptional regulation of the IGF signaling pathway by amino acids and insulin-like growth factors during myogenesis in Atlantic salmon. PLoS One. 2010.

64. Fuentes EN, Valdés JA, Molina A, Björnsson BT. Regulation of skeletal muscle growth in fish by the growth hormone - Insulin-like growth factor system. Gen Comp Endocrinol. 2013. 